\title{
Infectious Diseases and Meat Production
}

\author{
Romain Espinosa ${ }^{1} \cdot$ Damian Tago $^{2} \cdot$ Nicolas Treich $^{3}$
}

Accepted: 13 July 2020 / Published online: 4 August 2020

(c) Springer Nature B.V. 2020

\begin{abstract}
Most infectious diseases in humans originate from animals. In this paper, we explore the role of animal farming and meat consumption in the emergence and amplification of infectious diseases. First, we discuss how meat production increases epidemic risks, either directly through increased contact with wild and farmed animals or indirectly through its impact on the environment (e.g., biodiversity loss, water use, climate change). Traditional food systems such as bushmeat and backyard farming increase the risks of disease transmission from wild animals, while intensive farming amplifies the impact of the disease due to the high density, genetic proximity, increased immunodeficiency, and live transport of farmed animals. Second, we describe the various direct and indirect costs of animal-based infectious diseases, and in particular, how these diseases can negatively impact the economy and the environment. Last, we discuss policies to reduce the social costs of infectious diseases. While existing regulatory frameworks such as the "One Health" approach focus on increasing farms' biosecurity and emergency preparedness, we emphasize the need to better align stakeholders' incentives and to reduce meat consumption. We discuss in particular the implementation of a "zoonotic" Pigouvian tax, and innovations such as insectbased food or cultured meat.
\end{abstract}

Keywords Infectious diseases $\cdot$ Meat production · Meat consumption · Biodiversity Prevention $\cdot$ Intensive farming $\cdot$ Regulation $\cdot$ Taxation

JEL Classification I18 · Q18 · Q57

\section{Introduction}

The COVID-19 pandemic invites us to reflect on infectious disease risk prevention policies. If the current emergency is to mitigate the impacts of this pandemic and address the induced economic and social damages, we must collectively improve our capacity to

Nicolas Treich

nicolas.treich@inrae.fr

1 CNRS, CREM, Rennes, France

2 Emergency Centre for Transboundary Animal Diseases, Food and Agriculture Organization of the UN, Regional Office for Asia and the Pacific, Bangkok, Thailand

3 Toulouse School of Economics, INRAE, Toulouse, France 
prevent the future risks of infectious disease outbreaks. In particular, we must better understand the mechanisms that increase the risk of the emergence of infectious diseases and their severity, and properly assess the role of economic development, globalization, trade, urbanization and population growth. In this paper, our objective is to specifically examine the role of animal farming and animal consumption in relation to epidemic outbreaks.

About $75 \%$ of emerging infectious diseases are zoonotic; that is, they are transmissible diseases between humans and animals. Zoonoses cause approximately one billion cases of illness in people and millions of deaths every year (Karesh et al. 2012). Many of these diseases have emerged only recently, such as the avian influenza H1N1, severe acute respiratory syndrome (SARS), West Nile virus, Nipah virus, and bovine spongiform encephalopathy (BSE). Additionally, endemic zoonotic diseases such as rabies and brucellosis continue unabated in many countries. The recent synthesis of the literature by Rohr et al. (2019) finds that, "since 1940, agricultural drivers were associated with $>25 \%$ of all-and $>50 \%$ of zoonotic-infectious diseases that emerged in humans, proportions that will likely increase as agriculture expands and intensifies".

While traditional animal food sources such as bushmeat and backyard farming increase the risks of disease spillover from wild animals, intensive animal farming creates conditions for the emergence and amplification of epidemics because of the physical and genetic proximity of the billions of animals, often in frail health, that are raised indoors every year (Coker et al. 2011). Moreover, animal farming likely contributes indirectly to the spread of pathogens from wild animals due to deforestation and biodiversity loss associated with the expansion of agricultural land use (Civitello et al. 2015). These threats may expand under global warming conditions, to which animal farming also contributes. Industrial animal farming is also an incubator for antimicrobial resistance, given that most antibiotics used worldwide are for farmed animals (O’Neill 2015), often for prophylactic use.

The social costs induced by animal infectious diseases can be significant, as the COVID19 pandemic shows. They include both direct human and animal health costs, but also the indirect economic costs of business activity reduction and the associated environmental impacts during and after an epidemic event, as well as the cost of preventive measures, such as farm and wild animal culling. Additionally, they include various other indirect costs linked to monitoring and preparedness measures. Moreover, these costs, as we will demonstrate, are largely supported by the public sector. They also tend to disproportionately hurt the poor; that is, those who lack insurance and safety nets and cannot adopt preventive measures without compromising their livelihoods.

The current COVID-19 pandemic is not an exogenous event. Its emergence, spread and severity depends on human actions. Even though this event is very specific and unprecedented, it should not be seen as anomalous and unexpected, or simply attributed to "bad luck". Between 2011 and 2018, the WHO tracked 1483 epidemic events in 172 countries (GPMB 2019), and six public health emergencies of international concern have been declared since 2009. Hence, meat production imposes great risks to our societies and the current prevention systems seem to have largely reached their limits. From this perspective, we are probably seeing an unusual policy window opening in response to the COVID-19 pandemic, as regulators as well as private investors are being pressured to consider how best to prevent the next crisis (FAIRR 2020).

Given the global threats posed by infectious diseases, it is time to reexamine our regulatory framework, and broadly address health risks at the human-animal-environment interface consistent with the "One Health" approach (UNEP 2020). We must reduce our exposure to the animals from which we can get infected, and thus complement the current risk management approach by means of improved regulation of the production 
of meat and a reduction of its consumption in developed countries. As a result, the risk of zoonotic disease should be reduced, while also reducing other externalities (e.g., climate change, air and water pollution). Economics can help to inform and design this broader regulatory framework by better aligning the incentives of food producers with the common good, and by using appropriate fiscal, informational and behavioral instruments to foster dietary changes and innovations.

The remainder of the paper is organized as follows. First, we discuss how meat production and consumption increases the risks of infectious diseases. Second, we discuss the costs associated with animal-based infectious diseases. Last, we discuss the policies that could be implemented in order to reduce the costs related to animal-based infectious diseases.

\section{The Role of Animal Farming and Meat Consumption}

The production and the consumption of animal-based products contributes to an increase in the risks of infectious diseases (see Fig. 1). The consumption of wild animals (or bushmeat) is an important driver of new zoonoses. Wild animals are indeed important reservoirs of infectious diseases, and most of the zoonotic pathogens originate from wildlife. Animal farming plays a major role in the emergence and the spread of zoonotic pathogens, as numerous common infectious diseases reach humans through domestic animals (e.g., smallpox, tuberculosis; Wolfe et al. 2007). Backyard farming involves important risks in its exposure to wild animals through means other than commercial production. Intensive farming may reduce the likelihood of pathogen introduction through biosecurity intervention but significantly increases the risks of amplification, spread and the mutation of pathogens once they enter farming facilities. In addition, the deforestation associated with the increased production of meat deteriorates natural habitats and biodiversity, which can indirectly increase epidemic events.

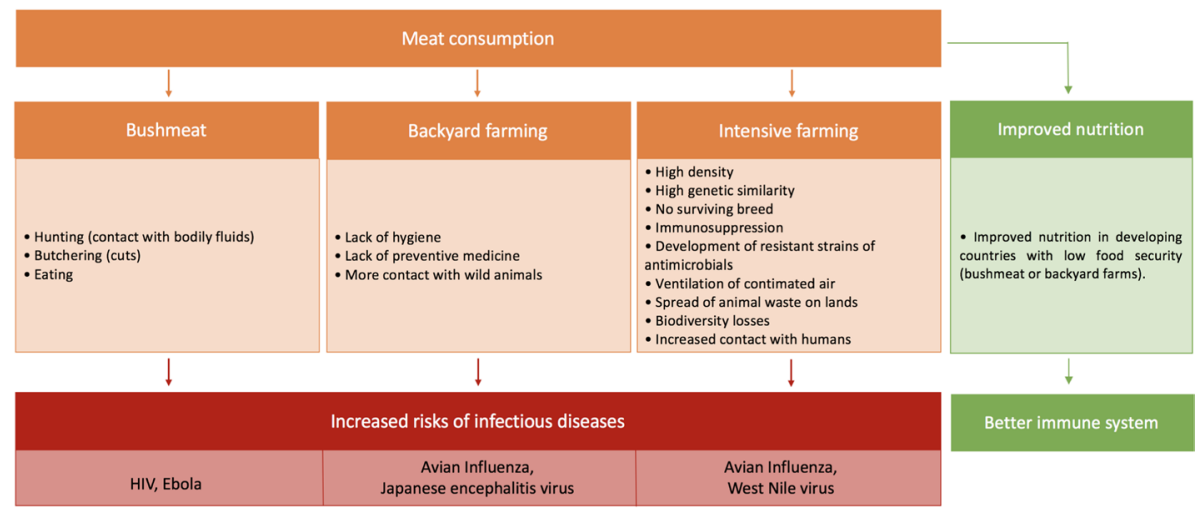

Fig. 1 Impact of meat consumption and production on infectious disease risks. Semi-intensive/extensive farming shares features of the backyard and the intensive farming methods 


\subsection{Bushmeat}

Scientists estimate that a large share $(72 \%)$ of zoonotic infections originate from wildlife (Jones et al. 2008), and increased contact with wild animals increases the risks of human exposure. Among the human-wildlife interactions, the hunting of wild animals, their butchering and the consumption of their flesh are important sources of contamination (Wolfe et al. 2005). Ebola is a well-known example of a zoonotic disease resulting from such activities, however, HIV (chimpanzees), anthrax (ungulates) and Simian foamy viruses (gorilla) also originate from wildlife hunting and eating. The use of wild bats as food also generates important problems (Kamins et al. 2015) as bats are unique in their propensity to host zoonotic viruses (Luis et al. 2013). The consumption and trade of bushmeat is especially important in developing countries, such as Botswana (Alexander et al. 2012), Ghana (Kamins et al. 2015), Cameroon (Wolfe et al. 2005), Sierra Leone (Subramanian 2012), and China (Zhou et al. 2014).

The use of bushmeat generates risks at several stages. The tracking, trapping, and slaying of wild animals increases the likelihood of exposure to pathogens, since hunters are in close contact with the animals and zoonoses can be transmitted by scratches or bites. Butchering is also a major source of zoonotic transmission as bodily fluids, bodily tissue and excrement further spread the pathogens. Local populations using bushmeat seem well aware of the associated disease risks but only a small minority take precautionary measures (LeBreton et al. 2006). Further evidence suggests that women involved in these activities might be at higher risk as they are more frequently involved in the butchering process (Subramanian 2012). The spread of the pathogenic agents from bushmeat can be further increased by illegal trade to more developed countries (Chaber et al. 2010; Smith et al. 2012). The popularity of consuming wild animals has contributed to the emergence of wildlife farming. Some studies claim that farming undomesticated animals that are usually hunted can help protect these species from extinction (Nogueira and Nogueira-Filho 2011). The increased supply is indeed expected to reduce the price of hunted animals, and, thus, reduce the attractiveness of hunting them (Damania and Bulte 2007). However, wildlife farming shows the important risks of infectious diseases as wild species that are bred in those farms are important hosts of pathogens. These animals are mostly sold in live animals or so-called wet markets.

\subsection{Backyard Farming}

Backyard farming, also called family farming, is characterized as a low input/low output system and is mainly (but not only) prevalent in developing countries (FAO 2020a). Backyard production systems (BPS) are a key element of food security in the developing countries that lack easy access to plant-based proteins (FAO 2020b). In these countries, the consumption of animal-based proteins can lead to better nutrition, which can bolster the immune system in fighting infections (Rohr et al. 2019). Previous findings have shown, for instance, that undernourishment is a risk factor for tuberculosis, but can, in some cases, mitigate hyperinflammatory diseases or parasitic proliferation. In addition, BPS have been the source of multiple epidemic outbreaks, even though the data suggest that it may be associated with fewer risks of outbreaks than those in intensified farming (Otte et al. 2007; La Sala et al. 2019). One reason for the relatively lower 
risks of epidemic outbreaks is that the current breeds of animals in BPS have survived previous epidemics (through natural selection) (Minga et al. 2004; Conan et al. 2012).

Nonetheless, the risks of epidemic outbreaks in BPS are significant and mainly result from the increased contact between domestic and wild animals (e.g., Henning et al. 2011; Wang et al. 2013). Although backyard farmed animals live in (or very close to) the family house, they are less likely to be monitored and handled than pets that live in the house, leading to lower disease detection rates (Whitehead and Roberts 2014). Low levels of biosecurity and poor levels of hygiene (e.g., the presence of rodents, lack of cleaning regimes/ equipment, no quarantine) may also increase the risks of infectious disease transmission (Conan et al. 2012). Moreover, BPS tend to make limited use of preventive medicines such as vaccines, which also leads to an increase in the risk of infection. However, the sanitary risks associated with BPS are heterogeneous: while most backyard farms have relatively low levels of biosecurity (e.g., Hamilton-West et al. 2012), some countries achieve high vaccination rates (e.g., Kamakawa et al. 2006).

\subsection{Intensive Farming}

Since the end of the Second World War, animal farming has undergone a transition from traditional small-scale farming methods to large-scale industrial operations (Graham et al. 2008). Developed countries, such as the USA or member states of the European Union, initiated those changes to respond to the growing demand in the consumption of animalbased products, and many developing countries with an increasing level of income, such as China, are following the same path (Zheng 2013). These intensive farming methods have led to the emergence of new agricultural models, in which hundreds or thousands of animals such as pigs and poultry, often of a single breed, are farmed in high-density closed facilities. In these intensive farms, animals have no outdoor access, remain in highly controlled and confined facilities, receive large doses of antimicrobials (Van Boeckel et al. 2015), and eat specific feed that replaces the foraging crops normally eaten (Graham et al. 2008). The intensification of animal husbandry has had the beneficial consequence of reducing the level of contact between farmed and wild animals. It has also reduced the likelihood that farmed animals come into contact with pathogens, and has thus helped to reduce disease risks. However, at least four negative consequences have resulted from this intensification that are likely to outweigh this benefit: (1) the increased scale of disease impact, (2) the immunosuppression of intensively farmed animals, (3) the risks of contamination for animals and humans living outside of farms, and (4) the risks associated with transportation.

Intensified farming has probably reduced the likelihood of the first contamination of farmed animals (entry risk), but has worsened the consequences of contamination within the farm (exposure risk): contamination events may have become less frequent but are far more severe. Dhingra et al. (2018) show for instance that intensified farming systems are responsible for a small share of the reassortments of avian influenzas (small or moderate risks) but concentrate most of the conversion events from low pathogenic to highly pathogenic viruses (high risks). Several factors contribute to this phenomenon. First, the high animal density in intensive farms leads to a greater spread of pathogens within the facilities (Graham et al. 2008; Cutler et al. 2010). Thousands of animals can be infected within a few days. Second, the selection of the most profitable species of farmed animals in intensive farms has led to a high level of genetic similarity. The genetic similarity among farmed animals facilitates the spread of the pathogens as all animals within the farms are 
immunologically naïve hosts, increasing the chance of catastrophic epidemics (Springbett et al. 2003; Drew 2011). In addition, genetic proximity and high density together offer ideal circumstances for the pathogens to mutate and evolve, which increases the risks of a mutation that is transmissible to humans (i.e., zoonoses). To avoid the risk of human contamination, as well as a spread to other facilities, intensive farms in high risk zones usually cull all animals once a case has been detected. For instance, during the H5N1 influenza epidemic, more than 230 million birds were killed by the disease or culled in counterepizootic measures (Karesh et al. 2012). To further minimize the risks, wild animals in the surroundings are also often culled (as was the case for wild boars with the African Swine Fever or for badgers with bovine tuberculosis). The killing of all animals in and around the farm prevents natural selection (that is, the survival of resistant breeds), and thus reduces their chance of adaptation to the pathogens in the future.

Animals bred in intensive farms are raised and transported in stressful conditions that weaken their immune systems, and, in turn, increase the risks of infection (El-Lethey et al. 2003; Rostagno 2009). To prevent the contamination of immunodeficient animals, intensive farms make intensive use of preventive antimicrobial drugs (Prophylaxis). The drug intakes increase disease risks in three ways. First, the intensive use of antimicrobials can suppress the immune system of farmed animals, which can lead to a vicious circle (Yang et al. 2017). Second, they facilitate the emergence of antimicrobial-resistant pathogenic strains (Gorbach 2001; Laxminarayan et al. 2013; Rohr et al. 2019). As stressed in the previous paragraph, intensive farms are ideal environments in which pathogens can mutate. The high number of potential hosts treated with antibiotics increases the chance of the mutation of the pathogen into a strain that is resistant to antimicrobial drugs. Third, an important share of antimicrobials end up in the environment, either directly, or through the water system, which further increases the risk of the development of resistant strains in wildlife and humans (O’Neill 2015).

The third type of externality due to the intensification of animal husbandry is the associated risk for domestic and wild animals that live in close proximity to farming facilities and also to the humans who work there. The risks of contamination of nearby animals mainly result from two sources. The first source of contamination is ventilation. In case of infection in a farm, the air coming out of the facilities via the ventilation systems carries the pathogens to the farm's surrounding neighborhood by means of wind and surface water transportation (Otte et al. 2007). Contamination within a facility is therefore likely to spread to animals outside of the facility, which, in turn, increases the risk of propagation. A second source of spillover is the indirect contamination of non-farmed animals via animal waste, including dead animals and fecal matter. Non-farmed animals can either come into contact with the waste when it is not stored in a confined place or when biosolids are spread on the land and can contaminate water (Graham et al. 2008; Jones et al. 2013). Last, the intensification of animal husbandry increases the risks for humans (Graham et al. 2008). Intensive farms require various people to be involved in the farming process (veterinarians, stock personnel, slaughterhouse workers, transportation teams), and neighbors of the facilities are also exposed to animal waste and ventilation risks.

Fourth, unlike backyard farming, where the produce is usually eaten at the local level, intensive farming produce is largely destined for exportation. With the reduction in transportation costs and the intensification of the livestock sector, the world trade in livestock and livestock products have increased substantially (Naylor et al. 2005). In 2017, approximately two billion animals were transported on ships (Levitt 2020). The journeys usually take place in very poor conditions and can last up to several weeks (Schuck Paim and Alonso 2020). During these journeys, animals live in close proximity, are 
immunosuppressed, and are in constant contact with other animals and with their own waste. The long-distance transportation of live animals and livestock products increases the risk and speed of a disease spreading (Di Nardo et al. 2011), such as with the African Swine Fever in China (Wang et al. 2013) and influenza A globally (Nelson et al. 2015).

\subsection{Extensive or Semi-intensive Farming}

Backyard and intensive farming represent two extreme models of meat production, and a variety of farms range between these two production methods (extensive farming, semiintensive farming, free-range farms, pastures, etc.). These intermediary production systems play an important role in the meat industry. For instance, cattle occupies $84 \%$ of the total area under agricultural and livestock use in Brazil (Nepstad et al. 2008) and is a major source of deforestation (Briceño-León 2007). The extensive production systems (EPS) share features with the two production systems. On the one hand, EPS seek to increase their production for commercial objectives (export). In this regard, these EPS generate similar externalities to intensive farming (transportation, close genetic proximity, prophylaxis, deforestation, etc.). On the other hand, animals in EPS are typically raised outside (pastures) or with outdoor access (free-range farms), which increase the chances of contact with wildlife. While animals in EPS are more likely to be monitored and have a greater access to preventive veterinary care than those in BPS, they have similar risks of contact with wildlife, which makes them more vulnerable to infectious diseases. Laddomada et al. (2019) show, for instance, that free-range pigs in Sardinia are an important vector of the African Swine Fever, as they share the same habitat as wild pigs (Costard et al. 2013; Iglesias et al. 2017). Similarly, pastoralism systems in Africa have been shown to be a risk factor for zoonotic diseases, including anthrax, brucellosis, Q-fever, rabies, and the Rift Valley Fever (Rass 2006; Desta 2016).

\subsection{Biodiversity and Other Indirect Environmental Impacts}

The increase in animal farming is also a threat to human health as it contributes to the loss of biodiversity. First, the global increase in meat consumption results in increased deforestation either to create new pasturages or to grow soy to feed farmed animals (De Sy et al. 2015). In addition to the negative impacts of deforestation on climate change, environmentalists have sought to understand whether or not the destruction of natural habitats and the associated loss of biodiversity increases the risks of new epidemics. Second, bushmeat production also contributes to the loss of biodiversity as it removes parts of the food chain from the natural habitat and leads to what conservationists call "empty landscapes" (Ripple et al. 2016).

The dilution effect states that biodiversity loss is associated with greater disease risks. Researchers who support the dilution effect explain that encroachment into natural habitats increases the number of small-bodied pathogen-carrying animals (such as rodents). The hyperabundance of these hosts has been shown to result from a significant decrease in the numbers of predators and competitors and an increase in available resources (Levi et al. 2016). The dilution effect has been supported by numerous studies (e.g., Ostfeld 2013); for instance, Young et al. (2014) show that the decline of wildlife in East Africa has resulted in a significant increase in rodent-borne zoonosis. In contrast, other researchers argue that more highly biodiverse environments may be associated with more diseases (Wood et al. 2014, 2016, 2017). Young et al. (2017) explain that biodiversity is multidimensional and 
can have multiple definitions, which makes it difficult to draw any general conclusions on the relationships between decreased biodiversity and diseases. Still, the current balance of evidence seems to support the dilution effect: in a meta-analysis of 202 effect sizes, Civitello et al. (2015) find broad evidence supporting that anthropogenic declines in biodiversity are associated with increased risks of human and wildlife diseases.

Meat production has other indirect environmental impacts on infectious diseases, in particular through water use. Agriculture uses more freshwater than any other human activity, with nearly a third required for livestock. Water used for growing animal feed accounts for $98 \%$ of the total water footprint of livestock production (Godfray et al. 2018). Although there is considerable variation in water footprint among types of meat and production systems, the production of animal-based products usually requires much more water per calorie or per protein than plant-based products (Poore and Nemecek 2018). However, the global indirect effect of animal production on infectious diseases through water use is complex. Agricultural development has driven the development of dams, reservoirs and irrigation schemes, which tend to increase infectious diseases such as malaria, and aggravates health burdens by macroparasites such as Schistosoma worms in Sub-Saharan Africa, partly because of an increased freshwater habitat for intermediate snail hosts (Ghebreyesus et al. 1999; Rohr et al. 2019; Sokolow et al. 2017). Yet, agricultural development has also caused a decline in the number and size of wetlands, which leads to a decrease in the emergence of infectious diseases (Rohr et al. 2019).

Animal farming worldwide generates approximately $14.5 \%$ of greenhouse gases emissions, and about twice this share if the opportunity cost of land use is accounted for (Poore and Nemecek 2018; Searchinger et al. 2018). This may generate additional indirect impacts on infectious diseases. Global climate change is shifting the distribution of infectious diseases in humans and wildlife (Lafferty 2009), and is making the future less predictable because of the nonlinear responses of parasites and hosts to temperature and climatic variability (Raffel et al. 2013). Climate change also affects biodiversity loss which has an impact on infectious diseases as discussed above. Moreover, climate change is expected to have major consequences for morbidity and mortality due to nutrient-deficient diets in the developing world. However, there still exists a high level of high scientific uncertainty and controversy around the climate change/disease relationship, and this issue is considered as an important topic for future research (Lafferty 2009; Rohr et al. 2011). Finally, we emphasize that agriculture, and especially animal agriculture, is also a major contributor to air pollution, mostly through the emission of ammonia, which is a precursor to fine particles (Tschofen et al. 2019). Although more research is needed on this issue, the health impacts of several infectious diseases, such as COVID-19, may increase when the air quality deteriorates, so that animal farming may indirectly aggravate health impacts through its contribution to air pollution.

\section{The Costs of Infectious Diseases}

All types of meat production increase zoonotic risks. Efficient food and health policies must take into consideration these externalities in their cost-benefit analysis. The burden of animal-based infectious diseases can be classified in terms of costs directly associated with the disease created by the host-pathogen interaction and those associated with prevention and control measures implemented (see Fig. 2). In the case of zoonoses, which are an element of a broad ecological concept of health systems, a holistic understanding 


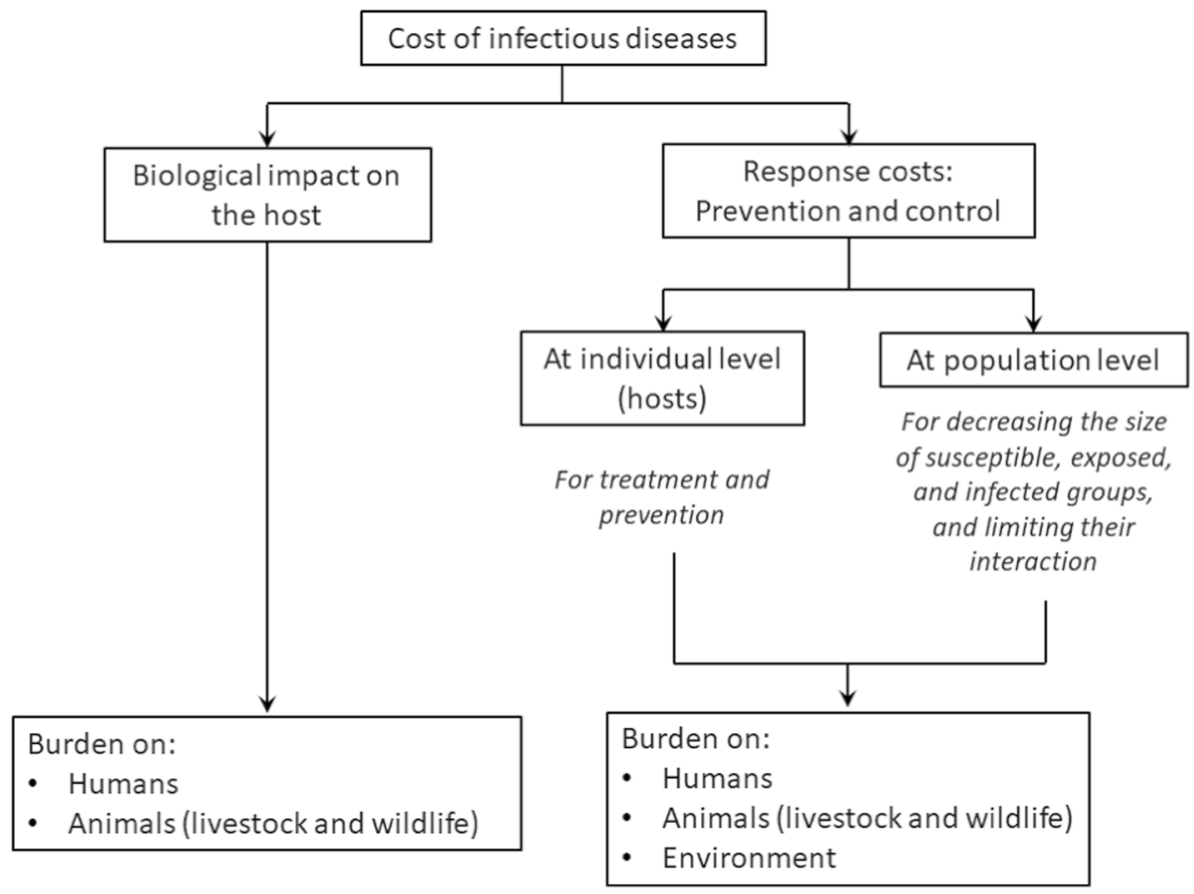

Fig. 2 Classification of the cost of infectious diseases

of their associated costs is required to better evaluate investments for preventing and controlling such diseases (Zinsstag et al. 2007). While efforts to estimate the burden of diseases have been fruitful (Lopez et al. 2006; Stein et al. 2007), the estimation of the burden of many zoonotic diseases remains incomplete (Torgerson and Macpherson 2011). For instance, assessing the cost of infectious animal diseases is often limited to farm costs (Bennett 2003) and more comprehensive methodologies result in estimates that are not fully comparable (Barratt et al. 2019; Saatkamp et al. 2016). Therefore, there is a need to further develop a widely accepted standardized approach to estimate the burden of infectious diseases, which includes the human, animal, and environmental dimensions (Rushton et al. 2018).

\subsection{Direct Costs: The Biological Impact}

The costs associated with a disease triggered by infection with pathogens, also referred to as the biological impact, includes illness, disability, and death in humans, as well as morbidity and mortality in animals (Narrod et al. 2012). Morbidity in livestock is associated with reduced productivity, including fertility problems (Knight-Jones and Rushton 2013), where the associated monetary value is usually attributed through existing market values. Livestock diseases have a direct impact on the livelihoods of people raising the animals, and more generally on stakeholders of the value chains of livestock and livestock products (Rushton 2003). The costs associated with the biological impact on animals could be higher-perhaps much higher-if an intrinsic value of animals is recognized instead of limiting the value of animals to their instrumental use to humans, as proposed by some 
conservationists (Batavia and Nelson 2017) and economists (Carlier and Treich 2020). Moral costs associated with humans' altruistic disutility regarding animal welfare loss could also be introduced based on standard valuation methods (Clark et al. 2017), but this has so far been ignored in animal health impact studies.

Two of the most studied diseases so far are Foot-and-mouth diseases (FMD) in cattle, and influenza in humans. The median annual cost of FMD due only to tangible production losses in affected livestock has been estimated at \$US7.6 billion worldwide (KnightJones and Rushton 2013). The annual global expected economic cost attributed only to the increased human mortality of pandemic influenza has been estimated to roughly \$US490 billion, or $0.7 \%$ of the global income (Fan et al. 2016). Further, there is an opportunity cost since the resources of the health system which are devoted to fighting the pandemic could have been used to treat the people with other diseases. Attributing a monetary value to wildlife and wildlife disease losses is more complicated since market valuation information remains scattered and does not capture all of the benefits associated with wildlife, such as contemplating benefits, seed dispersal, and even enhancing the carbon storage capacity of forests (Chardonnet et al. 2002; Berzaghi et al. 2019). Non-market approaches have been adopted to address this challenge but there exists a longstanding debate around its appropriateness (Stevens et al. 1991).

Influenza has been identified as the most likely pathogen to cause a severe pandemic (Madhav et al. 2017), with the H7N9 subtype ranking the highest regarding potential pandemic risk according to the US Centers for Disease Control and Prevention (CDC 2017). A zoonotic disease prioritization exercise conducted in seven low- and middle-income countries ranked zoonotic influenza as one of the top-three zoonoses of the highest concern (Salyer et al. 2017). Therefore, the pandemic risk associated with the raising of livestock differs by species, with swine and poultry identified as the most common hosts of zoonotic influenza viruses (WHO 2018).

\subsection{Indirect Costs: The Response}

When responding to infectious events, measures to prevent and control the spread of diseases are usually implemented. At the individual level, such measures aim at reducing the risk of infection (prevention) and mitigating the impact of the disease (treatment). At the population level, the goal is to reduce the size of susceptible, exposed, and infected groups, as well as to limit contact between these groups. These measures can be implemented by governments in order to protect global health, but they can also be the result of self-protective behaviors (Funk et al. 2010). Declaring a notifiable disease can trigger bans from importing countries, which can lead to substantial economic losses for the exporting countries (Blayney et al. 2006).

Although necessary to reduce the biological impact of infectious diseases, most preventive and control measures are costly, and such costs should - to the greatest possible extent-be carefully analyzed when assessing interventions, especially when they are implemented on a large scale. On the animal side, measures include the application of curative treatments and preventive interventions, such as vaccination and enhanced biosecurity, but also in the costs related to setting up surveillance systems (FAO 2016), and limiting disease transmission, such as market interventions (Peiris et al. 2016), animal movement controls (Fèvre et al. 2006), and mass culling. Some of these interventions induce substantial economic costs to stakeholders along the livestock value chain and a significant level of animal suffering (te Beest et al. 2011). For instance, with the 
African Swine Fever, there was a contraction of more than $40 \%$ in China's swine inventory within the first year (Haley and Gale 2020), which represents almost a quarter of the global swine herd. Culling operations involving thousands of animals are logistically challenging and usually come at the expense of animal welfare. While some of these measures are needed to control infectious diseases, some others seem unjustified and can threaten wildlife species (Zhao 2020).

In humans, curative treatments are prescribed and vaccination campaigns are implemented if available. Enhanced hygiene in human settings, such as hand-washing or maskwearing, and social distancing measures, including isolation and quarantine, are adopted in the early stages of an outbreak, but they may not be sufficient to contain an epidemic (Wilder-Smith and Freedman 2020). As the situation evolves, governments may take more aggressive measures to contain the spread, ranging from school closures (Viner et al. 2020) to declaring temporary curfews and imposing lockdowns in entire cities (Lau et al. 2020). Preventive measures of this nature halt economic activity, fuel unemployment (OECD 2020a), disrupt supply chains of essential goods and services (FAO 2020c), and ultimately compromise the progress made towards the United Nations Sustainable Development Goals (Solberg and Akufo-Addo 2020).

During the COVID-19 pandemic, the impact of each subsequent month of strict containment measures has been estimated to be the equivalent to a loss in GDP growth of two percentage points (OECD 2020b). Moreover, essential health services have been disrupted and catastrophic scenarios seem likely if the curtailment of such services extends, ranging from an increase in new HIV infections among children, now up by more than $70 \%$ in some African countries (Jewell et al. 2020), to a decrease in the delivery of childhood vaccines in the US (Santoli et al. 2020). Using a general equilibrium model, McKibbin and Sidorenko (2006) estimate that an extreme pandemic influenza event could cost \$US4.4 trillion to the global economy, leading to income losses exceeding $50 \%$ of the gross national income in some low- and middle-income countries.

As shown during the COVID-19 pandemic, the environment in which prevention and control measures are implemented is characterized by a high degree of uncertainty. Such uncertainty has an additional toll on the aggregate demand, employment, trade, and the functioning of financial markets, which exacerbates the challenges for recovery after the pandemic is under control (Leduc and Liu 2020). Although preventive and control measures should be designed according to scientific evidence, the urgency and fear generated by epidemics can coerce people to rush and to implement measures that lead to additional costs. Some examples that have raised concerns among the scientific community are the adoption of treatments that have not been validated (FitzGerald 2020) or discriminatory behaviors towards stigmatized groups (Rzymski and Nowicki 2020), the costs of which are hard to quantify.

On the environmental dimension, infectious diseases can have mixed consequences. Helm (2020) differentiates short- and longer-term environmental impacts expected from a pandemic, based on the COVID-19 experience. On the one hand, short-term impacts can be positive, such as the reduction of greenhouse gas emissions due to the contraction in economic activity or the increased connectivity between animal populations; on the other hand, additional waste related to disposable protective gear, as well as reduced environmental monitoring and regulation enforcement during a lockdown, are some of the challenges posed during a pandemic. For instance, hospitals at the epicenter of China's epidemic increased their medical waste by more than $350 \%$ compared with pre-outbreak levels (Klemeš et al. 2020; Zambrano-Monserrate et al. 2020). Moreover, immediate climate action may be seen as a less pressing issue by policymakers, which can lead to a 
relaxation of environmental regulations and diverting resources in order to mitigate the economic costs of the pandemic.

In the longer-term, Helm identifies three policy options that countries may put in place as a response to sharp declines in GDP attributed to the COVID-19 pandemic: monetary easing, fiscal stimuli and infrastructure packages. These measures all aim to stimulate the aggregate demand but can come with negative environmental impacts in the longer term. To counteract this risk, such measures should be complemented with environmental policies, such as those promoting investments in renewables and nuclear electricity, or in other natural capital enhancement projects. The author also identifies potential impacts on globalization and trade, intergenerational imbalances and consumer behavior, which can ultimately have an effect on the environment but which are hard to predict.

\subsection{The Unequal Burden of Infectious Diseases}

Infectious diseases also have an impact on inequality, as they tend to disproportionately affect the poor. Poverty and inequality create conditions that facilitate the transmission of infectious diseases, which can further contribute to unequal burdens of morbidity and mortality (Quinn and Kumar 2014; Holtgrave and Crosby 2003). The COVID-19 mortality risk amongst the poorest populations could be exacerbated considering that such populations are more likely to suffer from chronic conditions and a lack of access to health services (Ahmed et al. 2020). Communities of color have also been disproportionately impacted by the COVID-19 pandemic in the US, due to structural factors that prevent those communities from practicing social distancing, such as their disproportionate participation in "essential jobs" (Van Dorn et al. 2020). A COVID-19 mass testing campaign conducted in San Francisco, revealed that transmission was higher amongst people in the low-income group (Fernandez and Weiler 2020) and those who cannot confine themselves at home due to the risk of losing their jobs, or because they are providing essential services.

Similar or even more severe challenges can be expected in developing countries characterized by large informal economies and the lack of safety nets. Overcrowded living conditions make the implementation of social distancing extremely difficult (Bong et al. 2020) and highly prevalent comorbidities can lead to higher infection and fatality rates (Dahab et al. 2020). For people employed in the informal sector, not working and staying home means losing their livelihoods and facing food insecurity (ILO 2020). Moreover, the capacity of intensive care units in low- and middle-income countries is limited and its expansion to avoid saturation levels may not be feasible (Hopman et al. 2020). Overwhelmed health systems are a major risk for developing countries as resources to deal with other diseases are reallocated in order to deal with the epidemic, leading to the disruption of routine health care.

\section{Improving the Current Regulation of Meat Production}

In the previous sections, we have discussed how animal farming and animal consumption may generate epidemic outbreaks and have described the various consequences of these outbreaks. To do so, we have presented a large set of scientific references in global health, animal health, environmental, agricultural, and economic sciences. In this section, we discuss the existing regulatory framework of animal infectious diseases, and some ways to improve it. 


\subsection{Existing Regulatory Framework}

Important regulatory structures have been put in place over the years in order to mitigate the risks associated with animal-based infectious diseases. They include various national and international biosecurity protocols and sanitary standards to monitor, prevent and control the transmission of infectious diseases, the waste products such as excrement or carcasses, the transport of live animals nationally and across borders, and the possibility of contamination during the slaughter and processing phases. The current regulatory framework recognizes the benefits of adopting a One Health approach to address global health threats at the interface of public health, animal health (both domestic and wildlife) and the environment. The One Health approach is a collaborative framework to enhance multidisciplinary and cross-sectoral mechanisms, at global, regional, and national levels, aiming at attaining optimal health for people, domestic animals, wildlife, plants, and the environment (Gibbs 2014).

Building on this approach, the recent Tripartite Guide to Addressing Zoonotic Diseases in Countries involving the Food and Agriculture Organization (FAO), the World Organisation for Animal Health (OIE) and the World Health Organization (WHO) emphasizes the importance of communication among and between stakeholders, strategic planning and emergency preparedness, surveillance of zoonotic diseases, information sharing, and risk assessment (FAO, WHO and OIE 2019). While the interest of the One Health approach seems to be widely accepted, its operationalization has proven challenging due to the lack of institutional structures that support coordination among sectors. The role of economics, as a discipline that examines trade-offs in scarce resource allocation, has been pointed as crucial in operationalizing the One Health approach (Häsler et al. 2012). This has been reflected in the engagement of the World Bank which developed an operational framework for One Health systems (World Bank Group 2018) that highlights the need for global, regional and national coordination (Table 1). Countries that provided an appropriate institutional structure to support One Health may be more successful in translating One Health into action. For example, Indonesia created the Coordinating Ministry of Human Development and Culture (Kemenko PMK), which was designated as the authority responsible for enforcing close coordination among relevant ministries to operationalize One Health. As a result, the government of Indonesia was able to develop an Antimicrobial Resistance National Action Plan that integrates the views and inputs of the Ministries of Health $(\mathrm{MOH})$, Agriculture (MOA), Finance (MOF), and Marine Affairs and Fisheries (MMAF), and which has been translated into actions, such as the implementation of surveillance systems in human and animal settings and multisectoral risk assessments.

This approach requires great deal of control and coordination, and necessitates important investments. It tends to favor the evolution towards intensification through large-scale industrial farms. Some animal health experts and policy makers in both developing and developed countries indeed appear to accept that industrial farming has higher biosecurity standards (Otte et al. 2007; Zhang et al. 2017). However, this trend towards intensification also generates an increase in sanitary risks because of the various factors exhibited in Sect. 2. The performance of agricultural intensification in terms of risk prevention seems at best questionable if we judge by the increasing number of emerging infectious diseases in recent years (Jones et al. 2008; Coker et al. 2011; Bui et al. 2017). For instance, Dhingra et al. (2018) find that from 1959 onwards there was a total of 39 independent events where a low pathogenic avian influenza converted into a 


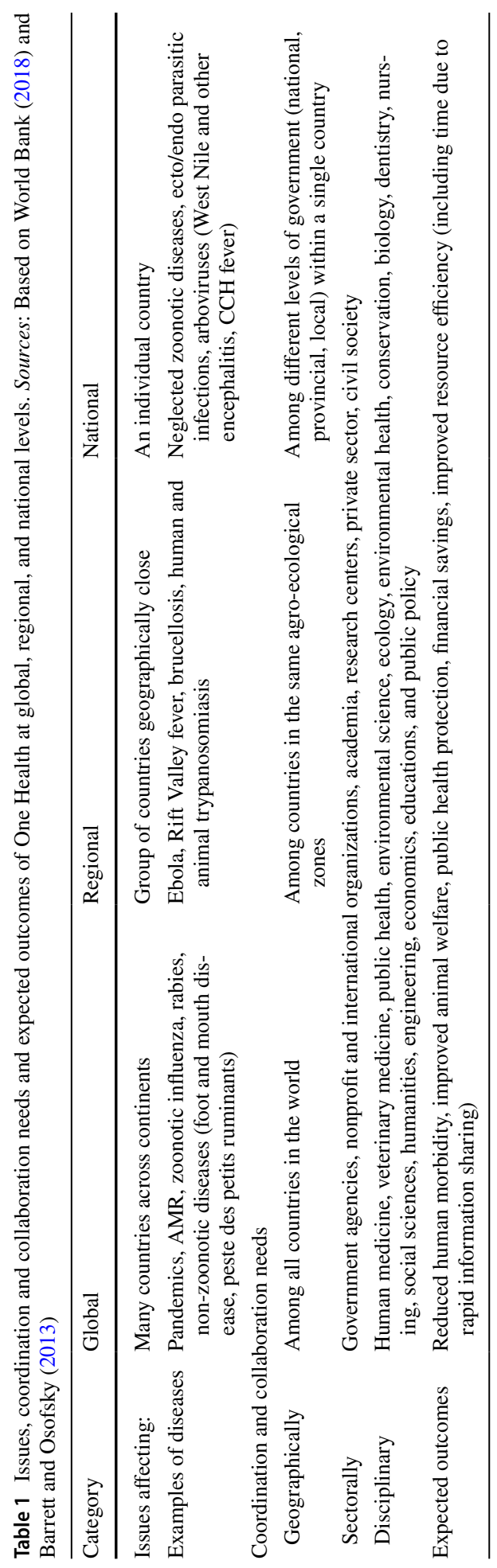


highly pathogenic one. All but two of these events were reported in commercial poultry production systems, and a majority of these events took place in high-income countries (we note, however, that there may be a reporting bias). In addition, the recent expansion and intensification of agriculture disproportionately occurs in tropical and developing countries where $75 \%$ of deaths are attributable to infectious diseases, where the risk of disease emergence is usually the greatest, and where the health systems are the most vulnerable (Rohr et al. 2019).

In 2010 , less than $18 \%$ of the poultry and $35 \%$ of the pigs raised globally belonged to backyard or extensive systems (Gilbert et al. 2015). Moreover, as GDP per capita is negatively correlated with the share of livestock raised in extensive systems (see Fig. 3), it can be expected that the livestock industry will intensify as developing countries get richer, at least under a business-as-usual scenario. According to Gilbert et al. (2015), countries with a GDP per capita above \$US10,000 (PPP) raise around 90\% of their poultry in intensive systems, which could be a result of stronger economic incentives to invest in intensification as the demand for animal products increases due to higher incomes, as well as increasing access to resources to fund the high fixed cost of factory farms in an economy with rising income. Therefore, focusing on intensive systems when designing better regulation and aligning incentives could be a good strategy to reduce the future risks of zoonotic infectious diseases.

There have been various commentaries and reports suggesting ways to improve the regulatory framework of animal-based infectious diseases (e.g., Karesh et al. 2012; Levi et al. 2014; Gostin 2016; GPMB 2019; Di Marco et al. 2020). These works typically emphasize the need to improve preparedness and coordination at a regional and global level and to accelerate research and development on vaccines and treatments, but do not seem to question the evolution of our food systems more broadly, in a context where current dietary choices appear unsustainable. It is also informative to observe that calls for improving regulation have been repeatedly made in the last decades, such as after the influenza A H1N1 outbreak (e.g., Coker et al. 2011). In the rest of this discussion, we emphasize
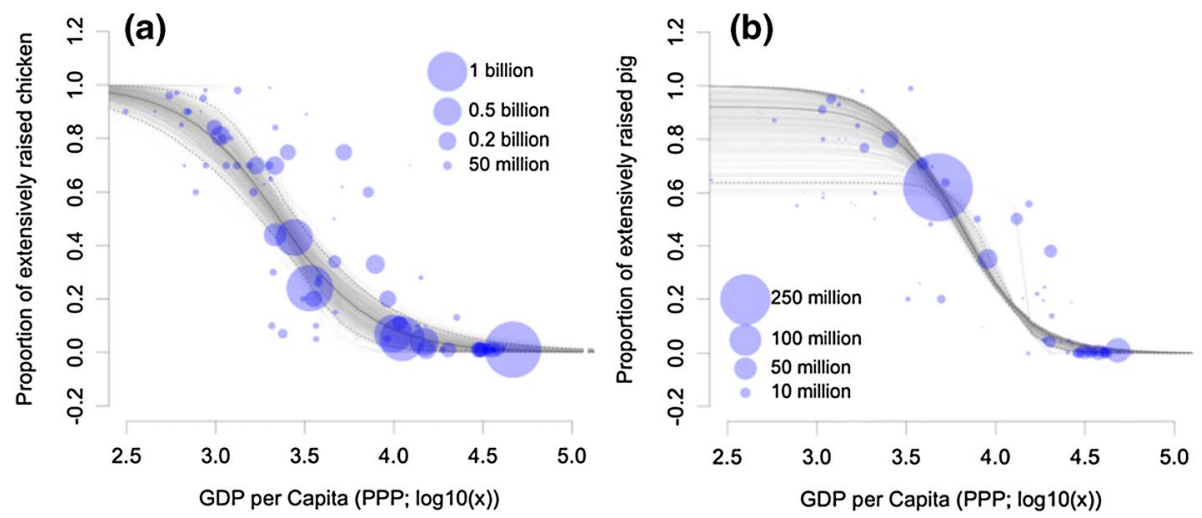

Fig. 3 Proportion of extensively raised chickens (a) and pigs (b) from Gilbert et al. (2015). Each dot represents a country with the size indicative of their stock of animals. The chicken extensive system follows FAO's sector 4 definition (village or backyard production with minimal biosecurity), while pig extensive system is characterized as usually unconfined, with typically $<10$ pigs, with low biosecurity with little or no health care. The complementary percentage (1-proportion of extensively raised) represents the proportion of animals raised in intensive systems for chickens, and the proportion of animals raised in intensive and semi-intensive systems for pigs 
two directions toward a better regulation that, we believe, have so far received insufficient attention both in academia and policy making fields. One direction concerns the supplyside and is presented now, while the other concerns the demand-side and is presented in the next section.

\subsection{Better Aligning Stakeholders' Incentives}

The first direction to reduce the zoonotic externalities of meat production, obvious for economists, consists of better aligning the stakeholders' incentives with the common good. We first observe that the consequences of epidemics are mostly supported by the public, first through people's morbidity and mortality and also because most financial consequences are borne by the health and public finance systems (see Sect. 3). Moreover, national or international agencies working on animal infectious disease prevention are usually publicly funded. In 2015, the funding for the investigation of emerging and zoonotic diseases in a single public US institution, the Centers for Disease Control, was nearly half a billion dollars (Schuck Paim and Alonso 2020). In their survey analysis, Rushton and Gilbert (2016) find that more than three quarters of the cost of worldwide veterinary services for animal health are funded by the public sector. Various other induced costs of animal outbreaks such as preventive animal culling may also be a burden for the taxpayer as farmers are often compensated ex post for the economic cost of culling. Farmers also often receive subsidies for vaccines, veterinary services, and the modernization of livestock facilities, which covers biosecurity (OECD 2017). The search and population control of wild animals living around farms is also typically carried out by public authorities; for instance, the control of African Swine Fever in South Korea was performed by the Ministry of Environment (100 persons), the Forest Service (200) and the military from five divisions (Jo and Gortázar 2020).

The consequence of the financial and logistic involvement of the public sector is that the infectious disease risks to animal and public health arising from livestock production may not be properly reflected in the costs of production, and in turn by the prices of animal source foods. This does not sound economically logical, in a context where the prices of food products do not well reflect their environmental externalities either (Bonnet et al. 2020; Nature Food 2020a). This regulatory failure largely favors the most polluting products, namely animal-based products over plant-based products (Poore and Nemecek 2018). If there are different ways of producing food associated with different levels of risk, and if one way is more risky than the others, it should be that the burden of risk is reflected in food prices in order to provide better incentives to consumers. Hence, costs should be better internalized by polluters, for example, farmers, meat processors, and eventually the consumers of animal products. The key question is how to do this.

Although farmers have clear incentives to prevent livestock disease, diminishing the prevalence of infectious animal disease generates positive externalities, so that government intervention is justified. However, appropriately designing public intervention requires a clear understanding of private incentives and strategic interactions (Hennessy 2007). For instance, farmers have private information about preventive biosecurity measures they adopt and about whether or not their herd is infected (Gramig et al. 2009). Some farmers may actually gain from an animal disease outbreak affecting others (Otte et al. 2007). The localization of farms matters for self-protection incentives (Hennessy 2007). Since the spread of infectious diseases depends on the openness of the production system, an appropriate trade policy is also warranted. Current economic policy approaches mostly focus on 
pandemic insurance, namely mobilizing resources for post-outbreak response and recovery in affected countries (Di Marco et al. 2020). However, if farmers know they are going to be compensated by the government, there is an additional moral hazard problem. Interestingly, approaches to ex post compensation related to epidemic diseases differ widely across countries: for instance, Australia establishes a cost-sharing rule between industry and government, Korea tailors government partial compensation to particular farmer profiles, while Chilean regulations do not foresee indemnities to producers in the case of animal disease outbreaks (OECD 2017).

When disease outbreaks occur, the initial source of contamination as well as some possible producers' negligence may be difficult to identify, complicating the implementation of sanctions and liability rules. Farmers should be incentivized to report a disease outbreak, especially for early reporting. To date, most regulatory measures of animal infectious diseases consist of "command-and-control" measures. It is not clear that these measures optimally account for the various strategic considerations involved, even in a second-best world (Gramig et al. 2009); at least, we are not aware of solid theoretical and evidence-based economic analysis to support existing regulations. The spread of animal infectious diseases is fundamentally a dynamic and uncertain phenomenon, which complicates understanding and policy implementation. The risk preferences and perceptions of farmers may also play an important role in the adoption of private control measures during an epidemic. We thus conclude this section by emphasizing the possible role for economists in an integrated interdisciplinary approach to better aid policy making in order to prevent the risks associated with animal infectious diseases (OECD 2017; OECD-Joint Risk Assessment 2020), as well as the research potential for environmental economists, who have a considerable experience in policy design in situations involving externalities, asymmetric information, dynamics, and uncertainty.

\section{A New Paradigm: Reducing Meat Consumption}

In this final part, we emphasize another regulatory direction. As illustrated in the previous section, essentially all the literature on animal infectious disease prevention, including various reports produced by international institutions such as FAO, WHO, OIE or the World Bank, concentrates on the supply side. It typically overlooks the issues related to the demand for meat, or essentially takes this demand as exogenously given. Interestingly, the recent United Nations report entitled Preventing the Next Pandemic identifies increasing demand for animal protein as a key driver of pandemics; however, it does not include the strategies to curb this demand among the proposed policy recommendations (UNEP 2020). Meat production increases because there is a demand for it. In 50 years, between 1960 and 2010, the global stocks of chickens and pigs increased by factors of 5 and 2.5, respectively (Gilbert et al. 2015). In Asia, during this period, meat consumption has been multiplied by 15 while population has been multiplied by 2.6. While designing the regulation of the supply side is highly complex as argued above, in contrast, reducing meat consumption appears to be a silver bullet. Since not one single pandemic in human history can be traced back to plants (Schuck Paim and Alonso 2020), substituting animal-based food with plant-based food should largely reduce overall zoonotic risks. In other words, a shift to more sustainable plant-based proteins should offer resilience where various forms of animal protein production have failed. This advantage should then be added to the long list of benefits of reducing meat 
consumption, including the decrease in greenhouse gases emissions, air pollution, land use, water use, water pollution, and likely the incidence of major noncommunicable diseases in developed countries (i.e., cancers, diabetes, cardiovascular diseases) (Godfray et al. 2018; Poore and Nemecek 2018; Tschofen et al. 2019; Willett et al. 2019).

Note that, while we emphasize the advantage of reducing meat consumption to reduce infectious disease risks, we did not discuss to any great extent the choice between different meat products, and thus between animal production systems, for instance between intensive versus extensive agriculture. One reason is that we discussed (to some degree) the relative weaknesses of each animal food systems in Sect. 2. In addition, this choice is still a matter of scientific debate, as illustrated, for instance, by the land sharing versus land sparing controversy regarding the impact of agriculture on biodiversity and losses of natural habitats (Kremen 2015). However, the main reason, as we will further argue below, is that reducing meat consumption and in turn downsizing meat production will probably deliver risk reduction benefits on a scale not achievable by marginally changing our existing animal food systems. That is, we believe that targeting the demand side of meat may be more effective than targeting the supply side for structural reasons.

Supply side strategies regarding the agricultural sector have indeed been notoriously complicated to implement in the past, as is well documented in the environmental domain for instance. It is common knowledge that the greening of common agricultural policy globally is a failure (Pe'er et al. 2014). Also, the agricultural sector has been largely exempted from climate change policies (e.g., carbon tax or emissions trading systems), and from air pollution regulation such as the Clean Air Act. One of the main reasons for this apparent regulatory failure is that the agricultural sector has strong political ties (Simon 2013), and is thus difficult to regulate. Moreover, this regulation is complicated by the high degree of competitiveness of world agricultural markets, and the fact that most farmers are poor or very poor, even in developed countries. Another reason is that regulating the agricultural sector is often perceived negatively by the public since it is associated with food insecurity and viewed as a barrier to the provision of basic needs.

This last concern is a legitimate issue, especially in developing countries. It should be recalled that about $10 \%$ of the world population live in a chronic state of malnutrition. The nutritional role that meat can play in countries facing malnutrition and food insecurity should not be neglected (see Fig. 1). For instance, Nielsen et al. (2017) estimates that more than one-third of the population of Latin America, Asia, and Africa harvests bushmeat. While this meat contributes little to rural household income (about 2\%) and mainly through own consumption (87\%), reliance on bushmeat appears more important in smaller and more remote communities [but not in China where more educated and richer people consume more bushmeat; Zhang and Yin (2014)]. Hence, regulating bushmeat consumption and trade is challenging, as the associated revenue can be essential for the subsistence of some families living in extreme poverty (De Merode et al. 2004; Kümpel et al. 2010). Also, after the COVID-19 pandemia which probably originated in wet markets in China, an increasing number of voices are calling for a ban of these markets (Zhang et al. 2014). But, again, wet markets support livelihoods, including those of small producers and farmers, and they are an important source of food for many communities (Nature Food 2020b). Moreover, some researchers note that bans could actually increase the infectious disease risks by shifting these activities into illegal and unregulated markets (Webster 2004; Nguyen et al. 2017) and accelerate the transition to intensive farming systems, which in turn present a higher risk for the evolution of highly pathogenic strains and disease amplification. Overall, we conclude that the case for regulating meat consumption in poorer countries is much weaker. 
An additional complexity for regulation is that the risks associated with infectious diseases have a catastrophic aspect. The COVID-19 pandemic economic relief plans announced by countries have allocated an unprecedented amount of resources, often representing around 5 and up to $20 \%$ of annual GDP. This catastrophic aspect makes the design of insurance schemes extremely difficult, if not impossible. There is then a simple economic rationale here: if the risk is difficult to manage and anticipate, and can hardly be shared once it occurs, the role of early self-protection becomes further emphasized; specifically, reducing the probability of a pandemic at the source. This can typically be achieved by reducing the consumption and production of animals. Therefore, we conclude that, in a growing and wealthier world, while the demand for meat is expected to drastically increase in the coming decades if no alternatives are adopted, and while animal agriculture tends to intensify everywhere in this world, it appears more and more urgent to find ways to curb the demand for meat (Godfray et al. 2018).

But how? Given that infectious diseases can be viewed as an externality generated by food choices, we could naturally consider a Pigouvian tax on the consumption of animal products, say a "zoonotic tax". While no country in the world has yet implemented a carbon tax on animal products, this raises the question of the alignment of a carbon tax and a zoonotic tax. A carbon tax mostly targets ruminants' meat and dairy products (Godfray et al. 2018; Bonnet et al. 2020). This may not be the case for a zoonotic tax, however, which would principally target pork and poultry meat in particular, as discussed in Sect. 3. Nevertheless, a global difficulty is that regulators may not have the societal license to tax meat products, whether for climate, infectious diseases or anything else. Furthermore, people seem strongly attached to eat meat because of a mix of biological, sociological and cultural factors, and it is extremely difficult to change ingrained food habits (Graça et al. 2015). Regulators may then have to resort to a subtle combination of fiscal, informational and behavioral instruments (Godfray et al. 2018; Bonnet et al. 2020). For instance, using nudges such as vegetarian default options (Hansen et al. 2019) or promoting step-by-step collective initiatives such as meatless days (Bonnet et al. 2020), may prove effective. Moreover, it may be important to review the role of plant-based diets in official nutritional recommendations/guidelines in order to account for the associated reduction in transmissible health risks induced by infectious diseases.

As a longer term strategy, regulators may rely on innovations and encourage the development of protein alternatives such as processed plant-based protein like tofu, seitan, mycoprotein, or fungus, as well as high tech options, such as plant-based burgers. Eating insects, for instance in the form of flour made from crickets or otherwise, may also be promising (van Huis 2019). Insects, which are evolutionary so distant from humans, should not pose great zoonotic risks (Dicke et al. 2020), although this is a controversial and underresearched issue (Galęcki and Sokół 2019). Moreover, farming and eating insects may avoid raising strong animal welfare issues, and the emission of pollution from insects is relatively low (Kim et al. 2020). Further, insects can be reared on feed that is unsuitable for livestock and which would otherwise have been wasted or have low economic value (World Economic Forum 2019). Finally, we emphasize the promise of cultured meat, namely meat produced by cultivating animal cells in the laboratory (Stephens et al. 2018; Treich 2020). In theory, this innovation permits the taste and texture of meat to be reproduced without having to manage the whole process: the rearing, transport and slaughter of animals. Since this technique readily eliminates contact with live animals (except in the early phase to obtain the animal cells), it should drastically reduce the risks of zoonotic disease.

To conclude, and in attempt to summarize succinctly our discussion of regulatory issues in Sects. 4 and 5, we provide Table 2 that includes some policy recommendations. 
Table 2 Summary of policy recommendations to regulate meat production (policies 1 and 2) and meat consumption (policies 3 to 5)

Policy recommendations for developed countries

1. Adjusting the compensation for the meat industry to reduce the moral hazard, and in particular to incentivize early reporting of epidemic outbreak

2. If any, conditioning the subsidies to farms on the production and transportation system (decreasing with the number of farmed and transported animals, decreasing with the genetic proximity, increasing with the use of vaccines, decreasing with the preventive use of antimicrobials)

3. Implementing a zoonotic tax on animal-based products

4. Implementing large-scale informational and nudging policies to reduce meat consumption and promote plant-based diets, and reviewing the role of plant-based diets in official nutritional recommendations/ guidelines

5. Subsidizing the development of animal-based food alternatives with lower zoonotic risks (insects, cultured meat)

Acknowledgements The authors acknowledge the editor, the guest editor, one anonymous reviewer, David Castellan, Madhur Dhingra, Sara Crompton Meade, Cynthia Schuck Paim and Lea Stapper for helpful comments. Romain Espinosa acknowledges financial support from the Centre de Recherche en Économie et Management and the ANR under Grant ANR-19-CE21-0005-01. Nicolas Treich acknowledges financial support from the ANR under Grant ANR-17-EURE-0010 (the Investissements d'Avenir program), INRAE, IAST and the FDIR chair.

\section{References}

Ahmed F, Ahmed NE, Pissarides C, Stiglitz J (2020) Why inequality could spread COVID-19. Lancet Public Health 5(5):e240

Alexander KA, Blackburn JK, Vandewalle ME, Pesapane R, Baipoledi EK, Elzer PH (2012) Buffalo, bush meat, and the zoonotic threat of brucellosis in Botswana. PloS one 7(3):e32842

Barratt AS, Rich KM, Eze JI, Porphyre T, Gunn GJ, Stott AW (2019) Framework for estimating indirect costs in animal health using time series analysis. Front Vet Sci 6:190

Barrett MA, Osofsky SA (2013) One Health: interdependence of people, other species, and the planet. In: Katz DL et al (eds) Jekel's epidemiology, biostatistics, preventive medicine, and public health, 4th edn. Elsevier/Saunders, Philadelphia

Batavia C, Nelson MP (2017) For goodness sake! What is intrinsic value and why should we care? Biol Conserv 209:366-376

Bennett R (2003) The 'direct costs' of livestock disease: the development of a system of models for the analysis of 30 endemic livestock diseases in Great Britain. J Agric Econ 54(1):55-71

Berzaghi F, Longo M, Ciais P, Blake S, Bretagnolle F, Vieira S, Doughty CE et al (2019) Carbon stocks in central African forests enhanced by elephant disturbance. Nat Geosci 12(9):725-729

Blayney DP, Dyck JH, Harvey DJ (2006) Economic effects of animal diseases linked to trade dependency, No. 1490-2016-127902, pp 23-29

Bong CL, Brasher C, Chikumba E, McDougall R, Mellin-Olsen J, Enright A (2020) The COVID-19 pandemic: effects on low-and middle-income countries. Anesth Analg 131(1):86-92

Bonnet C, Bouamra Z, Requillart V, Treich N (2020) Regulating meat consumption: how to improve health, the environment and animal welfare. Food Policy. https://doi.org/10.1016/j.foodpol.2020.101847

Briceño-León R (2007) Chagas disease and globalization of the Amazon. Cadernos de Saúde Pública 23:S33-S40

Bui CM, Chughtai AA, Adam DC et al (2017) An overview of the epidemiology and emergence of influenza A infection in humans over time. Arch Public Health 75:15

Carlier A, Treich N (2020) Directly valuing animal welfare in (environmental) economics. Int Rev Environ Resour Econ 14:113-152

CDC (2017) Influenza risk assessment tool (IRAT). CDC, Atlanta, GA. https://www.cdc.gov/flu/pandemicresources/tools/irat-virus-summaries.htm. Accessed 19 May 2020 
Chaber AL, Allebone-Webb S, Lignereux Y, Cunningham AA, Marcus Rowcliffe J (2010) The scale of illegal meat importation from Africa to Europe via Paris. Conserv Lett 3(5):317-321

Chardonnet P, Clers BD, Fischer J, Gerhold R, Jori F, Lamarque F (2002) The value of wildlife. Revue Scientifique et Technique-Office International des Epizooties 21(1):15-52

Civitello DJ, Cohen J, Fatima H, Halstead NT, Liriano J, McMahon TA, Rohr JR et al (2015) Biodiversity inhibits parasites: broad evidence for the dilution effect. Proc Natl Acad Sci 112(28):8667-8671

Clark B, Stewart GB, Panzone LA, Kyriazakis I, Frewer LJ (2017) Citizens, consumers and farm animal welfare: a meta-analysis of willingness-to-pay studies. Food Policy 68:112-127

Coker R et al (2011) Towards a conceptual framework to support one-health research for policy on emerging zoonoses. Lancet Infect Dis 11:P326-P331

Conan A, Goutard FL, Sorn S, Vong S (2012) Biosecurity measures for backyard poultry in developing countries: a systematic review. BMC Vet Res 8(1):240

Costard S, Mur L, Lubroth J, Sanchez-Vizcaino JM, Pfeiffer DU (2013) Epidemiology of African swine fever virus. Virus Res 173(1):191-197

Cutler SJ, Fooks AR, Van der Poel WH (2010) Public health threat of new, reemerging, and neglected zoonoses in the industrialized world. Emerg Infect Dis 16(1):1

Dahab M, van Zandvoort K, Flasche S, Warsame A, Spiegel PB, Waldman RJ, Checchi F (2020) COVID19 control in low-income settings and displaced populations: what can realistically be done. London School of Hygiene \& Tropical Medicine, London

Damania R, Bulte EH (2007) The economics of wildlife farming and endangered species conservation. Ecol Econ 62(3-4):461-472

De Merode E, Homewood K, Cowlishaw G (2004) The value of bushmeat and other wild foods to rural households living in extreme poverty in Democratic Republic of Congo. Biol Conserv 118(5):573-581

De Sy V, Herold M, Achard F, Beuchle R, Clevers JGPW, Lindquist E, Verchot L (2015) Land use patterns and related carbon losses following deforestation in South America. Environ Res Lett 10(12):124004

Desta AH (2016) Pastoralism and the issue of zoonoses in Ethiopia. J Biol Agric Healthc 6(7):21-27

Dhingra MS, Artois J, Dellicour S, Lemey P, Dauphin G, Von Dobschuetz S, Van Boeckel TP, Castellan DM, Morzaria S, Gilbert M (2018) Geographical and historical patterns in the emergences of novel highly pathogenic avian influenza (HPAI) H5 and H7 viruses in poultry. Front Vet Sci 5:84

Di Marco M et al (2020) Sustainable development must account for pandemic risk. Proc Natl Acad Sci 117:8

Di Nardo A, Knowles NJ, Paton DJ (2011) Combining livestock trade patterns with phylogenetics to help understand the spread of foot and mouth disease in sub-Saharan Africa, the Middle East and Southeast Asia. Revue Scientifique et Technique-OIE 30(1):63

Dicke M et al (2020) Edible insects unlikely to contribute to transmission of coronavirus SARS-CoV-2. J Insects Food Feed. https://doi.org/10.3920/JIFF2020.0039

Drew TW (2011) The emergence and evolution of swine viral diseases: to what extent have husbandry systems and global trade contributed to their distribution and diversity? Revue Scientifique et TechniqueOIE 30(1):95

El-Lethey H, Huber-Eicher B, Jungi TW (2003) Exploration of stress-induced immunosuppression in chickens reveals both stress-resistant and stress-susceptible antigen responses. Vet Immunol Immunopathol 95(3-4):91-101

FAIRR (2020) An industry infected animal agriculture in a post-COVID world. https://www.fairr.org/artic le/industry-infected/. Accessed July 2020

Fan VY, Jamison DT, Summers LH (2016) The inclusive cost of pandemic influenza risk (No. w22137). National Bureau of Economic Research

FAO (2016). Economic analysis of animal diseases. FAO Animal Production and Health Guidelines, No. 18 , Rome

FAO (2020a) Gateway to poultry production and products. http://www.fao.org/poultry-production-products/ production/production-systems/family-poultry-production/en/. Accessed July 2020

FAO (2020b) Backyard poultry provides an alternative way to sustain food security and nutrition in Syria. http://www.fao.org/in-action/backyard-poultry-provides-an-alternative-way-to-sustain-food-securityand-nutrition-in-syria/en/. Accessed July 2020

FAO (2020c) COVID-19 and the risk to food supply chains: how to respond? https://doi.org/10.4060/ca838 8 en

FAO, OIE and WHO (2019) A tripartite guide to addressing zoonotic diseases in countries

Fernandez E, Weiler N (2020) Initial results of mission district COVID-19 testing announced. UCSF News, May 4 2020. https://www.ucsf.edu/news/2020/05/417356/initial-results-mission-district-covid-19testing-announced 
Fèvre EM, Bronsvoort BMDC, Hamilton KA, Cleaveland S (2006) Animal movements and the spread of infectious diseases. Trends Microbiol 14(3):125-131

FitzGerald GA (2020) Misguided drug advice for COVID-19. Science 367(6485):1434

Food N (2020a) The true cost of food. Nat Food 1:185

Food N (2020b) Exploring wet markets. Nat Food 1:241

Funk S, Salathé M, Jansen VA (2010) Modelling the influence of human behaviour on the spread of infectious diseases: a review. J R Soc Interface 7(50):1247-1256

Galęcki R, Sokół R (2019) A parasitological evaluation of edible insects and their role in the transmission of parasitic diseases to humans and animals. PLoS ONE 14(7):e0219303. https://doi. org/10.1371/journal.pone.0219303

Ghebreyesus TA et al (1999) Incidence of malaria among children living near dams in northern Ethiopia: community based incidence survey. BMJ 319:663-666

Gibbs EPJ (2014) The evolution of One Health: a decade of progress and challenges for the future. Vet Rec 174(4):85-91

Gilbert M, Conchedda G, Van Boeckel TP, Cinardi G, Linard C, Nicolas G, Robinson TP et al (2015) Income disparities and the global distribution of intensively farmed chicken and pigs. PLoS ONE 10(7):e0133381

Global Preparedness Monitoring Board (GPMB) (2019) The world at risk: annual report on global preparedness for health emergencies

Godfray HCJ, Aveyard P, Garnett T, Hall JW, Key TJ, Lorimer J, Pierrehumbert RT, Scarborough P, Springmann M, Jebb SA (2018) Meat consumption, health, and the environment. Science 361:5324

Gorbach SL (2001) Antimicrobial use in animal feed-time to stop. N Engl J Med 345:1202-1203

Gostin LO (2016) Global health security after Ebola: four global commissions. Milbank Q 94:34-38

Graça J, Calheiros MM, Oliveira A (2015) Attached to meat? (Un)Willingness and intentions to adopt a more plant-based diet. Appetite 95:113-125

Graham JP, Leibler JH, Price LB, Otte JM, Pfeiffer DU, Tiensin T, Silbergeld EK (2008) The animalhuman interface and infectious disease in industrial food animal production: rethinking biosecurity and biocontainment. Public Health Rep 123(3):282-299

Gramig BM, Horan RD, Wolf CA (2009) Livestock disease indemnity design when moral hazard is followed by adverse selection. Am J Agric Econ 91:627-641

Haley M, Gale F (2020) African swine fever shrinks pork production in China, swells demand for imported pork. Amber Waves: The Economics of Food, Farming, Natural Resources, and Rural America, 2020 (1490-2020-880)

Hamilton-West C, Rojas H, Pinto J, Orozco J, Hervé-Claude LP, Urcelay S (2012) Characterization of backyard poultry production systems and disease risk in the central zone of Chile. Res Vet Sci 93(1):121-124

Hansen PG, Schilling M, Malthesen MS (2019) Nudging healthy and sustainable food choices: three randomized controlled field experiments using a vegetarian lunch-default as a normative signal. J Public Health. https://doi.org/10.1093/pubmed/fdz154

Häsler B, Gilbert W, Jones BA, Pfeiffer DU, Rushton J, Otte MJ (2012) The economic value of One Health in relation to the mitigation of zoonotic disease risks. In: Mackenzie JS, et al (eds) One Health: the human-animal-environment interfaces in emerging infectious diseases. Springer, Berlin, pp 127-151

Helm D (2020) The environmental impacts of the coronavirus. Environ Resour Econ. https://doi. org/10.1007/s10640-020-00426-z

Hennessy DA (2007) Biosecurity and the spread of animal infectious disease. Am J Agric Econ $89: 1226-1231$

Henning J, Henning KA, Morton JM, Long NT, Ha NT, Vu LT, Meers J et al (2011) Highly pathogenic avian influenza (H5N1) in ducks and in-contact chickens in backyard and smallholder commercial duck farms in Viet Nam. Prev Vet Med 101(3-4):229-240

Holtgrave DR, Crosby RA (2003) Social capital, poverty, and income inequality as predictors of gonorrhoea, syphilis, chlamydia and AIDS case rates in the United States. Sex Transm Infect 79(1):62-64

Hopman J, Allegranzi B, Mehtar S (2020) Managing COVID-19 in low-and middle-income countries. JAMA 323(16):1549-1550

Iglesias I, Rodriguez A, Feliziani F, Rolesu S, De la Torre A (2017) Spatio-temporal analysis of African Swine Fever in Sardinia (2012-2014): trends in domestic pigs and wild boar. Transbound Emerg Dis 64(2):656-662

ILO (2020) COVID-19 crisis and the informal economy: immediate responses and policy challenges

Jewell BL, Smith JA, Hallett TB (2020) The potential impact of interruptions to HIV services: a modelling case study for South Africa. medRxiv 
Jo Y-S, Gortázar C (2020) African swine fever in wild boar, South Korea, 2019. Transbound Emerg Dis. https://doi.org/10.1111/tbed.13532

Jones KE, Patel NG, Levy MA, Storeygard A, Balk D, Gittleman JL, Daszak P (2008) Global trends in emerging infectious diseases. Nature 451(7181):990-993

Jones BA, Grace D, Kock R, Alonso S, Rushton J, Said MY, Pfeiffer DU et al (2013) Zoonosis emergence linked to agricultural intensification and environmental change. Proc Natl Acad Sci 110(21):8399-8404

Kamakawa A, Thu HTV, Yamada S (2006) Epidemiological survey of viral diseases of pigs in the Mekong delta of Vietnam between 1999 and 2003. Vet Microbiol 118(1-2):47-56

Kamins AO, Rowcliffe JM, Ntiamoa-Baidu Y, Cunningham AA, Wood JL, Restif O (2015) Characteristics and risk perceptions of Ghanaians potentially exposed to bat-borne zoonoses through bushmeat. EcoHealth 12(1):104-120

Karesh WB et al (2012) Ecology of zoonoses: natural and unnatural histories. Lancet 380:1936-1945

Kim BF et al (2020) Country-specific dietary shifts to mitigate climate and water crises. Glob Environ Change 62:101926

Klemeš JJ, Van Fan Y, Tan RR, Jiang P (2020) Minimising the present and future plastic waste, energy and environmental footprints related to COVID-19. Renew Sustain Energy Rev 127:109883

Knight-Jones TJD, Rushton J (2013) The economic impacts of foot and mouth disease-What are they, how big are they and where do they occur? Preventive Veterinary Medicine 112(3-4):161-173

Kremen C (2015) Reframing the land-sparing/land-sharing debate for biodiversity conservation. Ann N Y Acad Sci 1355:52-76

Kümpel NF, Milner-Gulland EJ, Cowlishaw G, Rowcliffe JM (2010) Incentives for hunting: the role of bushmeat in the household economy in rural Equatorial Guinea. Hum Ecol 38(2):251-264

La Sala LF, Burgos JM, Blanco DE, Stevens KB, Fernández AR, Capobianco G, Pérez AM et al (2019) Spatial modelling for low pathogenicity avian influenza virus at the interface of wild birds and backyard poultry. Transbound Emerg Dis 66(4):1493-1505

Laddomada A, Rolesu S, Loi F, Cappai S, Oggiano A, Madrau MP, Cherchi S et al (2019) Surveillance and control of African Swine Fever in free-ranging pigs in Sardinia. Transbound Emerg Dis 66(3):1114-1119

Lafferty KD (2009) The ecology of climate change and infectious diseases. Ecology 90:888-900

Lau H, Khosrawipour V, Kocbach P, Mikolajczyk A, Schubert J, Bania J, Khosrawipour T (2020) The positive impact of lockdown in Wuhan on containing the COVID-19 outbreak in China. J Travel Med. https://doi.org/10.1093/jtm/taaa037

Laxminarayan R, Duse A, Wattal C, Zaidi AK, Wertheim HF, Sumpradit N, Greko C (2013) Antibiotic resistance- - the need for globalsolutions. Lancet Infect Dis 13(12):1057-1098

LeBreton M, Prosser AT, Tamoufe U, Sateren W, Mpoudi-Ngole E, Diffo JLD, Wolfe ND et al (2006) Patterns of bushmeat hunting and perceptions of disease risk among central African communities. Anim Conserv 9(4):357-363

Leduc S, Liu Z (2020) The uncertainty channel of the coronavirus. FRBSF Econ Lett 2020(07):1-05

Levi J, Segal LM, Lieberman DA, May K, Laurent R (2014) Outbreaks: protecting Americans from infectious diseases. https://collections.nlm.nih.gov/catalog/nlm:nlmuid-101654702-pdf

Levi T, Massey AL, Holt RD, Keesing F, Ostfeld RS, Peres CA (2016) Does biodiversity protect humans against infectious disease? Comment. Ecology 97(2):536-542

Levitt T (2020) Two billion and rising: the global trade in live animals in eight charts. Guardian. https ://www.theguardian.com/environment/2020/jan/20/two-billion-and-rising-the-global-trade-in-liveanimals-in-eight-charts. Accessed July 2020

Lopez AD, Mathers CD, Ezzati M, Jamison DT, Murray CJ (eds) (2006) Global burden of disease and risk factors. The World Bank, Washington, D.C.

Luis AD, Hayman DT, O'Shea TJ, Cryan PM, Gilbert AT, Pulliam JR, Fooks AR et al (2013) A comparison of bats and rodents as reservoirs of zoonotic viruses: are bats special? Proc R Soc B Biol Sci 280(1756):20122753

Madhav N, Oppenheim B, Gallivan M, Mulembakani P, Rubin E, Wolfe N (2017) Pandemics: risks, impacts, and mitigation. In: Jamison DT, Gelband H, Horton S, et al (eds) Disease control priorities: improving health and reducing poverty, 3rd edn. The International Bank for Reconstruction and Development/The World Bank, Washington, D.C

McKibbin WJ, Sidorenko A (2006) Global macroeconomic consequences of pandemic influenza. Lowy Institute for International Policy, Sydney, p 79

Minga UM, Msoffe PL, Gwakisa PS (2004) Biodiversity (variation) in disease resistance and in pathogens within rural chicken populations. In: International Health Network for Family Poultry (INFD). World Poultry Congress, June 2004, pp 8-13 
Narrod C, Zinsstag J, Tiongco M (2012) A one health framework for estimating the economic costs of zoonotic diseases on society. Ecohealth 9(2):150-162

Naylor R, Steinfeld H, Falcon W, Galloway J, Smil V, Bradford E, Mooney H (2005) Losing the links between livestock and land. Science 310(5754):1621-1622

Nelson MI, Viboud C, Vincent AL, Culhane MR, Detmer SE, Wentworth DE, et al (2015) Global migration of influenza A viruses in swine. Nat Commun 6(1):1-11. https://doi.org/10.1038/ncomms7696

Nepstad DC, Stickler CM, Filho BS, Merry F (2008) Interactions among Amazon land use, forests and climate: prospects for a near-term forest tipping point. Philos Trans R Soc B Biol Sci 363(1498):1737-1746

Nguyen TTT, Fearnley L, Dinh XT, Tran TTA, Tran TT, Nguyen VT, Tripodi A et al (2017) A stakeholder survey on live bird market closures policy for controlling highly pathogenic Avian influenza in Vietnam. Front Vet Sci 4:136

Nielsen MR, Pouliot M, Meilby H, Smith-Hall C, Angelsen A (2017) Global patterns and determinants of the economic importance of bushmeat. Biol Conserv 215:277-287

Nogueira SS, Nogueira-Filho SL (2011) Wildlife farming: an alternative to unsustainable hunting and deforestation in Neotropical forests? Biodivers Conserv 20(7):1385-1397

O'Neill J (2015) Antimicrobials in agriculture and the environment: reducing unnecessary use and waste. The review on antimicrobial resistance, pp 1-44. http://www.naturallivestockfarming.com/wp-conte nt/uploads/2016/02/Antimicrobials-in-agriculture-and-the-environment-Reducing-unnecessary-useand-waste.pdf

OECD (2017) Producer incentives in livestock disease management. OECD Publishing, Paris

OECD (2020a) Supporting people and companies to deal with the COVID-19 virus: options for an immediate employment and social-policy response. https://www.oecd.org/coronavirus/policy-responses/ supporting-people-and-companies-to-deal-with-the-covid-19-virus-options-for-an-immediate-emplo yment-and-social-policy-response/. Accessed 11 May 2020

OECD (2020b) Evaluating the initial impact of COVID-19 containment measures on economic activity. https://www.oecd.org/coronavirus/policy-responses/evaluating-the-initial-impact-of-covid-19-conta inment-measures-on-economic-activity/. Accessed 11 May 2020

OECD, Joint Risk Assessment (2020) The first step in resilience programming. http://www.oecd.org/dac/ Experts\%20Group\%20working\%20paper\%20-\%20Joint\%20risk\%20assessment.pdf. Accessed July 2020

Ostfeld RS (2013) A Candide response to Panglossian accusations by Randolph and Dobson: biodiversity buffers disease. Parasitology 140(10):1196-1198

Otte J, Roland-Holst D, Pfeiffer D, Soares-Magalhaes R, Rushton J, Graham J, Silbergeld E (2007) Industrial livestock production and global health risks. Food and Agriculture Organization of the United Nations, Pro-Poor Livestock Policy Initiative Research Report

Pe'er G et al (2014) EU agricultural reform fails on biodiversity. Science 344:1090-1092

Peiris JM, Cowling BJ, Wu JT, Feng L, Guan Y, Yu H, Leung GM (2016) Interventions to reduce zoonotic and pandemic risks from avian influenza in Asia. Lancet Infect Dis 16(2):252-258

Poore J, Nemecek T (2018) Reducing food's environmental impacts through producers and consumers. Science 360:987-992

Quinn SC, Kumar S (2014) Health inequalities and infectious disease epidemics: a challenge for global health security. Biosecur Bioterror 12(5):263-273

Raffel T, Romansic J, Halstead N et al (2013) Disease and thermal acclimation in a more variable and unpredictable climate. Nat Clim Change 3:146-151

Rass N (2006) Policies and strategies to address the vulnerability of pastoralists in sub-Saharan Africa. Propoor livestock policy initiative (PPLPI) working paper series, 37. FAO, Rome

Ripple WJ, Abernethy K, Betts MG, Chapron G, Dirzo R, Galetti M, Newsome TM et al (2016) Bushmeat hunting and extinction risk to the world's mammals. R Soc open Sci 3(10):160498

Rohr JR, Dobson AP, Johnson PT et al (2011) Frontiers in climate change-disease research. Trends Ecol Evol 26(6):270-277

Rohr JR, Barrett CB, Civitello DJ, Craft ME, Delius B, DeLeo GA, Remais JV et al (2019) Emerging human infectious diseases and the links to global food production. Nat Sustain 2(6):445-456

Rostagno MH (2009) Can stress in farm animals increase food safety risk? Foodborne Pathog Dis 6(7):767-776

Rushton J (2003) Methods for the assessment of livestock development interventions in smallholder livestock systems. FAO, Pro-Poor Livestock Policy Initiative, Working paper no. 4. http://www.fao.org/ ag/againfo/projects/en/pplpi/project_docs.html. Accessed July 2020

Rushton J, Gilbert W (2016) The economics of animal health: direct and indirect costs of animal disease outbreaks, working paper. World Organisation for Animal Health, Paris 
Rushton J, Bruce M, Bellet C, Torgerson P, Shaw A, Marsh T, Wood P et al (2018) Initiation of global burden of animal diseases programme. Lancet 392(10147):538-540

Rzymski P, Nowicki M (2020) Preventing COVID-19 prejudice in academia. Science 367(6484):1313

Saatkamp HW, Mourits MCM, Howe KS (2016) A framework for categorization of the economic impacts of outbreaks of highly contagious livestock diseases. Transbound Emerg Dis 63(4):422-434

Salyer SJ, Silver R, Simone K, Behravesh CB (2017) Prioritizing zoonoses for global health capacity building - themes from One Health zoonotic disease workshops in 7 countries, 2014-2016. Emerg Infect Dis 23(Suppl 1):S55

Santoli JM, Lindley MC, DeSilva MB, Kharbanda EO, Daley MF, Galloway L, Weintrabu E (2020) Effects of the COVID-19 pandemic on routine pediatric vaccine ordering and administration-United States, 2020. MMWR. Morbidity and mortality weekly report, 69

Schuck Paim C, Alonso WJ (2020) Pandemics, global health and consumer choices. CriaEditora.com

Searchinger TD, Wirsenius S, Beringer T, Dumas P (2018) Assessing the efficiency of changes in land use for mitigating climate change. Nature 564:249-253

Simon (2013) Meatonomics: how the rigged economics of meat and dairy make you consume too muchand how to eat better, live longer, and spend smarter. Conari Press, Newburyport

Smith KM, Anthony SJ, Switzer WM, Epstein JH, Seimon T, Jia H, Sleeman JM et al (2012) Zoonotic viruses associated with illegally imported wildlife products. PLoS ONE 7(1):e29505

Sokolow SH et al (2017) Nearly 400 million people are at higher risk of schistosomiasis because dams block the migration of snail-eating river prawns. Philos Trans R Soc B 372:20160127

Solberg E, Akufo-Addo NAD (2020) Amid the coronavirus pandemic, the SDGs will help us build back better. Thomson Reuters Foundation. https://news.trust.org/item/20200416073143-62tz1/. Accessed 11 May 2020

Springbett AJ, MacKenzie K, Woolliams JA, Bishop SC (2003) The contribution of genetic diversity to the spread of infectious diseases in livestock populations. Genetics 165(3):1465-1474

Stein C, Kuchenmüller T, Hendrickx S, Prüss-Ústün A, Wolfson L, Engels D, Schlundt J (2007) The global burden of disease assessments-WHO is responsible? PLoS Negl Trop Dis 1(3):e161

Stephens N et al (2018) Bringing cultured meat to market: technical, socio-political, and regulatory challenges in cellular agriculture. Trends Food Sci Technol 78:155-166

Stevens TH, Echeverria J, Glass RJ, Hager T, More TA (1991) Measuring the existence value of wildlife: what do CVM estimates really show? Land Econ 67(4):390-400

Subramanian M (2012) Zoonotic disease risk and the bushmeat trade: assessing awareness among hunters and traders in Sierra Leone. Ecohealth 9(4):471-482

te Beest DE, Hagenaars TJ, Stegeman JA, Koopmans MP, van Boven M (2011) Risk based culling for highly infectious diseases of livestock. Vet Res 42(1):81

Torgerson PR, Macpherson CN (2011) The socioeconomic burden of parasitic zoonoses: global trends. Vet Parasitol 182(1):79-95

Treich N (2020) Some economics of cultured meat. Mimeo

Tschofen P, Azevedo IL, Muller NZ (2019) Fine particulate matter damages and value added in the US economy. Proc Natl Acad Sci 116(40):19857-19862

United Nations Environment Programme and International Livestock Research Institute (UNEP) (2020) Preventing the next pandemic: zoonotic diseases and how to break the chain of transmission. Nairobi, Kenya

Van Boeckel TP, Brower C, Gilbert M, Grenfell BT, Levin SA, Robinson TP, Laxminarayan R et al (2015) Global trends in antimicrobial use in food animals. Proc Natl Acad Sci 112(18):5649-5654

Van Dorn A, Cooney RE, Sabin ML (2020) COVID-19 exacerbating inequalities in the US. Lancet 395(10232):1243-1244

van Huis A (2019) Insects as food and feed, a new emerging agricultural sector: a review. J Insects Food Feed 6(1):27-44

Viner RM, Russell SJ, Croker H, Packer J, Ward J, Stansfield C, Booy R et al (2020) School closure and management practices during coronavirus outbreaks including COVID-19: a rapid systematic review. Lancet Child Adolesc Health 4(5):397-404

Wang Y, Jiang Z, Jin Z, Tan H, Xu B (2013) Risk factors for infectious diseases in backyard poultry farms in the Poyang Lake area, China. PLoS ONE 8(6):e67366

Webster RG (2004) Wet markets - a continuing source of severe acute respiratory syndrome and influenza? Lancet 363(9404):234-236

Whitehead ML, Roberts V (2014) Backyard poultry: legislation, zoonoses and disease prevention. J Small Anim Pract 55(10):487-496

WHO (2018) Influenza (Avian and other zoonotic). http://www.who.int/en/news-room/fact-sheets/detail/ influenza-(avian-and-otherzoonotic). Accessed 19 May 2020 
Wilder-Smith A, Freedman DO (2020) Isolation, quarantine, social distancing and community containment: pivotal role for old-style public health measures in the novel coronavirus (2019-nCoV) outbreak. J Travel Med 27(2):taaa020

Willett W et al (2019) Food in the Anthropocene: the EAT-Lancet Commission on healthy diets from sustainable food systems. Lancet 393:447-492

Wolfe ND, Daszak P, Kilpatrick AM, Burke DS (2005) Bushmeat hunting, deforestation, and prediction of zoonotic disease. Emerg Infect Dis 11(12):1822

Wolfe ND, Dunavan CP, Diamond J (2007) Origins of major human infectious diseases. Nature 447(7142):279-283

Wood CL, Lafferty KD, DeLeo G, Young HS, Hudson PJ, Kuris AM (2014) Does biodiversity protect humans against infectious disease? Ecology 95(4):817-832

Wood CL, Lafferty KD, DeLeo G, Young HS, Hudson PJ, Kuris AM (2016) Does biodiversity protect humans against infectious disease? Reply. Ecology 97(2):542-545

Wood CL, McInturff A, Young HS, Kim D, Lafferty KD (2017) Human infectious disease burdens decrease with urbanization but not with biodiversity. Philos Trans R Soc B Biol Sci 372(1722):20160122

World Bank Group (2018) Operational framework for strengthening human, animal, and environmental public health systems at their interface

World Economic Forum (2019) Meat: the future series-alternative proteins. White paper, Prepared by the Oxford Martin School

Yang JH, Bhargava P, McCloskey D, Mao N, Palsson BO, Collins JJ (2017) Antibiotic-induced changes to the host metabolic environment inhibit drug efficacy and alter immune function. Cell Host Microbe 22(6):757-765

Young HS, Dirzo R, Helgen KM, McCauley DJ, Billeter SA, Kosoy MY, Dittmar K et al (2014) Declines in large wildlife increase landscape-level prevalence of rodent-borne disease in Africa. Proc Natl Acad Sci 111(19):7036-7041

Young HS, Wood CL, Kilpatrick AM, Lafferty KD, Nunn CL, Vincent JR (2017) Conservation, biodiversity and infectious disease: scientific evidence and policy implications. Phil Trans R Soc. https://doi. org/10.1098/rstb.2016.0124

Zambrano-Monserrate MA, Ruano MA, Sanchez-Alcalde L (2020) Indirect effects of COVID-19 on the environment. Sci Tot Environ 728:138813

Zhang L, Yin F (2014) Wildlife consumption and conservation awareness in China: a long way to go. Biodivers Conserv 23:2371-2381

Zhang T, Bi Y, Tian H, Li X, Liu D, Wu Y, Chang J et al (2014) Human infection with influenza virus A (H10N8) from live poultry markets, China, 2014. Emerg Infect Dis 20(12):2076

Zhang X, Zhao Y, Mu G (2017) Economic factors contributing to the outbreaks of indigenous major infectious diseases from domestic animals in China between 2000 and 2016: a multicountry study. Lancet 390:S48

Zhao H (2020) COVID-19 drives new threat to bats in China. Science 367(6485):1436

Zheng C (2013) Assessing environmental impacts of Chinese livestock policies: an agent-based approach. Wageningen University, Wageningen

Zhou ZM, Zhou Y, Newman C, Macdonald DW (2014) Scaling up pangolin protection in China. Front Ecol Environ 12(2):97-98

Zinsstag J, Schelling E, Roth F, Bonfoh B, De Savigny D, Tanner M (2007) Human benefits of animal interventions for zoonosis control. Emerg Infect Dis 13(4):527

Publisher's Note Springer Nature remains neutral with regard to jurisdictional claims in published maps and institutional affiliations. 